\title{
Surfaces
}

\section{README. WRITING NOTES}

\section{Andrew Benjamin}

Volume 3, 1993

URI : https://id.erudit.org/iderudit/1065102ar

DOI : https://doi.org/10.7202/1065102ar

Aller au sommaire du numéro

Éditeur(s)

Les Presses de l’Université de Montréal

\section{ISSN}

1188-2492 (imprimé)

1200-5320 (numérique)

Découvrir la revue

\section{Citer cet article}

Benjamin, A. (1993). README. WRITING NOTES. Surfaces, 3.

https://doi.org/10.7202/1065102ar
Résumé de l'article

Méditation sur la temporalité de l'écriture.
Copyright (c) Andrew Benjamin, 1993

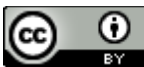

Ce document est protégé par la loi sur le droit d'auteur. L'utilisation des services d'Érudit (y compris la reproduction) est assujettie à sa politique d'utilisation que vous pouvez consulter en ligne.

https://apropos.erudit.org/fr/usagers/politique-dutilisation/
Cet article est diffusé et préservé par Érudit.

Érudit est un consortium interuniversitaire sans but lucratif composé de l'Université de Montréal, l'Université Laval et l'Université du Québec à Montréal. Il a pour mission la promotion et la valorisation de la recherche. https://www.erudit.org/fr/ 


\title{
README \\ WRITING NOTES
}

Andrew Benjamin

\begin{abstract}
Meditations on the temporality of writing.

RÉSUMÉ
\end{abstract}

Méditation sur la temporalité de l'écriture.

With what will it be necessary to write? Initially it may have been envisaged as a forlorn and at times deepening task that, in its work -- in the work of its unfolding -- all that was there would have come to bear down on the activity itself. Working away in the night of thought at an activity that while awaiting daybreak holds it away -- holds it back -- for with its arrival, in the breaking of that time, the activity comes to be sundered by what it allows to be awaited. The elements of these still apposite images -- apposite because of their enacted distancing of ends -- will need to be questioned. How will the "all" of this day, the "all" that is there, be understood? What is it that arrives? What ends? Finally, though there can be no real end to the procession of questions, can the sundering be redeemed? In other words can there be a holding beyond the sway of metaphysical destruction, and thus the holding of an-other destruction? One will hold to the other's destruction.

At the very least, there will be questions.

Within this promulgation of mood -- too quickly to be thought of as a tone set by questions -- there lies a way of proceeding; a way that occurs with the question. Not in the essential nature of the question nor in what is held therein. What will count here is that to which the question holds. Holding to it, the question -- and this will be true of questioning in general -- is allowed, 
by this act, by the holding outside that becomes a turning inside, to be held as a question. The question gives itself within the act -- thus within the acting out -- of its own self-constitution.

The question in succumbing to the process that it identifies -- the act of questioning -- will work to preclude finality by holding to a finitude that opens. The infinite and the finite are recast such that they are held together rather than inevitably excluding. Here the demise of the inevitable retains.

The question's opening, its holding fast.

Being a question will be a turning from an outside, constituting an inside as a question. All that is harboured -- held within by the question -- is its enacted constitution. The truth of the question is its constitution as a question. A movement, that in bringing outside and inside together resists the enforced dominance of that formal set-up.

In abeyance, therefore, will be that take on the question in which the question -- the truth to which it gestures -- is thought to be already carried by the question itself. In the place of the already present will be the insistence of the process of constitution. The continuity of activity will comprise the truth of the question. The question's propriety.

The move from the abeyance of the dominance of the already present towards the continuity of activity enacts the other possibility for destruction. Again, it will be a possibility that retains and in retaining allows centrality to be given to repetition.

The question of writing's activity; is it to be taken as an opening that gives to thought the possibility of its own enactment? The process of its being enacted? And yet the act -- the enacted task that must inevitably characterize activity -- may seem, by that very designation, to be marked by the necessity of a loss; a specific loss enjoining bereavement. What is intended, the task of enacting, may always seem to fail. In failing what will emerge as obligatory -- the next step after the presence of an impossibility -will be mourning. This via negativa however must be greeted with suspicion. Perhaps what needs to be elicited is another passion?

Passion may work away at the negative. Not as a work that negates but as a movement that works from an-other place.

In all of these notes -- even in the admitted luxury of their presentation, the continuity of a compilation that need not recognise the demands of a certain narrativity -- what is there as forcing presentation is the ineliminable presence of time. Of the times in question there are two that insist. The first is the work of speed. How is the question of time's speed to be understood? 
The second, and it is a question that will already be marked by an enforcing actuality, is the present. What is the time of the present? It should not be thought that these times admit of any easy separation.

Already there seems to be the division and with it the periodisation of the essay. Perhaps their circumvention will occur by conceding their initial presence while allowing an-other possibility? The difficulty will always be the thinking and the presenting of any specific other. What this demand brings with it are requirements whose provision will involve more than specific formal procedures.

Alterity needs to be thought outside the confining logic of the either/or, and beyond the work of positing. Alterity is neither the given other, nor is it posited difference. Difference must be located both in terms of its own constitution and in that which differentiates it from either variety or simple diversity. Again there will be the centrality of movement; again there will be the ineliminability of ontology.

Continuing means that what must be worked with will eschew the negative by affirming the discovery that the via negativa is a path that emerges from (thus also with) the recognition of the impossibility of a specific project. It arises because of an assumed possibility and accepted point of departure. It is a path that is constructed, it is not just there to be uncovered. However, the necessity of construction may be forgotten. The inherent threat therefore lies in either the naturalising of the negative, its having an ineliminable presence; or the assumption of a possible necessary completion, what in the end would amount to a banalising of the theological.

The assumption of the necessity of the via negativa turns failure -- and with it the acceptance of its originally failing -- from that which may occasion mourning to what will give rise to the most profound melancholy. The latter because the loss will have emerged as original. Posited as original its work will be taken as the transgression of an original promise. A promise which from the beginning was already betrayed. Naturalising arising with forgetting links promise and myth.

The original promise is not the work of myth. It is the myth itself whose work is the activity of ritual.

Here another way may have arisen. It will not arise by accepting the mythic status of this original and thus the original loss at the origin. Such an origin may be mythic, its significance however lies in its being held at the present. Perhaps it is a myth that works within the actuality of much contemporary philosophical thinking. As such it would be a myth with its own activity; its own specific ritual. And yet the language of myth and ritual while exercising a certain attraction and laying hold thereby to the sedulous will obviate the force of the present; the force of its present time. 
Emphasising the impossible, accepting it as that which has occurred will have necessitated accepting -- an acceptation tout court -- an original possibility. When what is given cannot be continued because it has become impossible such a move stills the possibility of repetition and accepts -accepts by assuming -- the original project as an original and therefore also as a unified projection. Again the movement of enacting is dismissed and thus the present unaccepted even though what the latter presents and the former allows endure as effective.

There will have to be a different "impossible". It must be allowed another possibility. The question that endures is how that process is to be thought? The initial part of any answer is that it is a thinking that takes place at the present.

The present arises as that which will come to insist. The present comes to insist by its being what will already have insisted. Here, in allowing this insistence, there is the possibility of both a philosophy of action and a philosophy of historical time. Presented as such they would comprise, in part, a philosophy of the present.

The locus of nihilism is given by the present. Nihilism is either maintained or subdued within the varying responses to the present's presence. It will be joined, ineliminably, to insistence. Furthermore with either the denial of insistence, the denial of the present's force, or with the connection being forgotten, what would amount to the disavowal of the present, what then appears as that which conditions thinking's presentation will be, once again, failure and negation. The continual work of the negative will have acquired a positive content because it will be taken as the only possibility. There will be, in addition, the assumption of its own inevitability.

What is harboured within the difficulty of formulating the work of the negative is its being done without. This is the direct challenge of the negative. There are two responses. The first will lie with repetition, with the possibility that repetition can operate beyond the dominance of the Same, allowing within the scope of that work a repetition in which difference figures. The second response will stem from the acknowledged complexity of work.

In the impossibility of its being there originally, the work of the negative is only naturalised in the effacing of the process that gives rise to it. The via negativa can only occur after the event. In being given priority it may always be taken -- mis-taken -- as the event.

Countering nihilism must involve more than a simple affirmation. The determinations at work within its coming to exercise a hold must also be implicated. Nihilism forms part of the present by its working to maintain, in part, conflict at the present; maintaining conflict within a setting to which it 
remains indifferent. While conflict will endure -- an endurance that will allow conflict's own complexity -- its movement will demand a different account. Conflict will demand a different setting.

"Countering" raises the problem of the language of opposition; the thought of the other possibility. It will have to be a language and a thinking other than that of a straightforward opposition. What counts as a language -- a regional language -- may have to change with the problem's attempted resolution. Thinking will comes to be rearticulated in terms of what is possible at the present. It will be here that because of the possible dominance of divergence over unity the present will emerge as a complex site. In being complex it will attest, once again, to the insistent force of conflict.

There will be a commitment to the primordial but it will pertain to process and therefore to a movement -- movements -- with effects/affects. It will be process that enables the cohabitation of the finite and the infinite. A cohabitation precluding the power of synthesis but which in its ceaseless working and ending of generality serves to connect -- one possible connection amongst many -- time and speed.

The initial difficulty, though it will be one with far greater extension, is how the place and the practice of recognition -- the recognition of this generative process -- is to be understood? Again, the question is far from simple since what is being asked pertains to another, and still more difficult interconnection. Here it will involve primordial presence, propriety and truth. It should not be thought that what is at issue here stems from the presence of differing values. What must be taken on is the presence of this difference at the present. Again time insists.

Present's time.

There is, with this difficult interconnection, the necessary presumption of another history. A rewriting of the present in which it is allowed a presence that works beyond the hold of the negative; in which what is given is not taken as attesting to the necessity of impossibility. How is this possibility, one which if it is followed brings with it an inescapable necessity, to avoid the charges of either naivety or a forced utopian vision?

The force of this question cannot be denied. What it brings to the fore is the problem of justification. How can the question -- By what right ......? -- be answered here? The only response is to continue working on the question; the continuity of its being questioned. Justification will become this outside possibility. Becoming it by a return which signals the effective presence of the movement of constitution in which the question is held up -- thus also held over -- as what it is. It will be the question that is given by its 
incorporating the demands to which it gives rise; again the constitution of the question as a question.

Time will mark out another possibility. Taking on the centrality of time will give rise to a repositioning of naivety and the utopian; their "original" place fraying within the present in which they are being worked through. With this process the former will have become the belief in the new beyond all mediation; provisionally the time of wishing. While what was first present as the utopian vision will come to be repositioned as the fusing of naivety and the future. Both of these reworkings will be positioned with the present as part of its own constitution.

What arises therefore is an-other time and thus the abeyance of the naive and the utopian. With it what also arises is an-other possibility for the new and therefore a different determination of the future. In the most straightforward sense this is the act of redemption.

Working away and working through will be that which opens up what was already possible. In allowing this opening they signal the other possibility. With them destruction will take on an-other life.

The other destruction would be one in which ending and totality taken as either original or complete no longer pertained because they came to be recognised as moments -- affects/effects -- of the process in which they are held. The primordality of a generative process will work away at the intermingling of failure and negation. And yet the work of that process cannot be inexorable the break within movement, the moment that allows the simple repetition of the Same to come undone, is neither negation nor metaphysical destruction, but an-other repetition. A repetition in which what occurs takes place again for the first time. This other repetition will allow the new to be given with the present, as part of it.

With each location -- each location within and as part of the present -- the present becomes the locus of different intensities and thus of different speeds. It is implicated therefore in its own complexity.

Giving the future a different place will mean locating its possibility as a condition of the present. Held at the present, held as being part of the present's time, by being part of that which works to maintain the present as incomplete, it emerges as hope.

Here hope is the consequence of the future's reincorporation into the present. It is not that which comes, as a mysterious other, it is there as that possibility in the present which may at any time be a mystery. As a possibility at the present hope is also, in part, constitutive of the present. 
Hope works, once more, to yield present intensity.

\section{Andrew Benjamin}

Department of Philosophy

University of Warwick

Surface Page d'Acceuil/Home Page 